\title{
Somaye Davoodi
}

Islamic Azad University, Shiraz, Iran

davodi.2011@gmail.com

\section{Leila Akbarpour}

$\mathrm{PhD}$ of Teaching English Language, Assistant Professor

Isamic Azad University, Shiraz, Iran

akbarpourleila@yahoo.com

Ehsan Hadipour

$\mathrm{PhD}$ of Teaching English Language, Assistant Professor

Isamic Azad University, Shiraz, Iran

e.ehadipour@gmail.com

\section{THE EFFECTS OF PSYCHOLOGICAL VARIABLES ON EFL TEACHERS ATTITUDE TOWARD TECHNOLOGY: CASE STUDY OF IRAN}

\begin{abstract}
Nowadays, with the fast development of information and communication technology, the role of technology in learning and teaching environment has remarkably increased and been stressed. To boost the influential use of technology in instruction and teaching, English language teachers could focus on strategies such as integrating pervious methods of teaching with new methods in which technological tools could be used, utilizing beneficial software, and create an interacting learning environment. The objective of the present study is to explore the impacts of psychological variables on teachers`attitude towards technology use. In this research, most versatile models like technology acceptance are used as the basis for developing a conceptual framework. Variables such as perceived usefulness, perceived ease of use, self-efficacy, subjective norms, compatibility, trialability and attitude are retrieved from these models. The participants of the present research are high school English language teachers in Shiraz. The researcher uses stratified sampling to identify a suitable sample from the population. The present study is conducted by using five questionnaires to evaluate and assess variables. The data are analyzed by means of path analysis to find the contribution of each independent variable to the dependent variables that ultimately predicted the final outcome. Self-efficacy, subjective norms, compatibility and trialability are found to be the determinants of perceived usefulness. However, perceived ease of use is found to be only affected by self-efficacy, subjective norms, and trialability, which in turn determined the attitude of teachers toward using technology in their teachings. The results suggest that the impact of trialability on attitude is meaningful. On the other hand, perceived usefulness has a significant influential effect on attitude. Subjective norms has an indirect but important effect on attitude, and self-efficacy has an indirect effect on attitude.
\end{abstract}

Keywords: teachers` attitude; perceived usefulness; perceived ease of use; self-efficacy; subjective norms; trialability.

\section{INTRODUCTION}

The problem statement. At the present time, information technology has penetrated in every aspect of our daily lives. Everywhere, in every organization and academic settings, computer literacy is of vast importance. With the introduction of new technological tools and resources, new ways of learning and teaching in multiple content areas and in multiple formats became accessible to students and teachers everywhere [1]. Additionally, with the technological developments, researchers and teachers were enabled to pursue more concise, systematic and data-based approaches, and apply more innovative methods and techniques in educational contexts. Another aspect of educational technology is its effective influence on teachers' learning and communication. Technology also enhances efficacy in syllabus design [2].

Despite the availability of many technological resources in academic settings, and their determinate effect in the improvement of teaching and learning, it seems that teachers rarely use them. According to [3], educational technology develops quite fast, but teachers do not 
accommodate at that speed. Park [4] believes that time and support are the most crucial factors in how much a teacher makes use of technology. Yet, it is the attitude of the teacher which determines the technology use; teachers who have a positive opinion towards the use of technology in educational contexts behave differently from their counterparts with a less positive attitude [5].The individual's beliefs about the impacts of technological instruments and her/his evaluation of these impacts define her/his attitude [6].

Many prior studies have investigated various aspects of technological developments in English teaching, solely from the point of view of the learners. This research examined technology acceptance from teachers viewpoint. Although in various pieces of research the relations between technology acceptance variables had been considered, the present study tried to add some other variables to technology acceptance model (TAM) and extend this model. Therefore the hypothesised research model was based on TAM plus some famous models like innovation diffusion theory and theory of reasoned action.

The article's goal. This study aimed at presenting a research model for examining English language teachers' acceptance and attitude. As the conceptual framework, the present paper advantaged theory of reasoned action, technology acceptance model, social cognitive theory, and innovation diffusion theory. The impacts of perceived usefulness, perceived ease of use, computer self-efficacy, subjective norms, compatibility, and trialability on teachers`attitude toward technology acceptance and use are issues which have been addressed in this study.

\section{THE THEORETICAL BACKGROUND}

Several attitude theories and models have proved the symbiotic relation between attitude and behavior. Fishbein and Ajzen`s [7] Theory of Reasoned Action (TRA) is among the most versatile theories of attitude. This theory is called the model of reasoned action due to its supposition that people's actions are mainly rational and based on analyzing existing information [8]. Regarding the Theory of Reasoned Action an individual's behavioral goals specify one's real manner. Behavioral goal is in turn specified by the individual's attitude toward this behavior and subjective norms regarding the performance of this behavior [9]. Behavioral goal is a measure of one's goal to act a special behavior, attitude is an individual's positive or negative emotions about acting the target behavior, and subjective norm is a person's recognition that most people who are significant to him/her think he or she should or should not act the behavior [10].

To properly describe and predict technology acceptance manners, Davis [11] designed a theoretically justified model. He selected the Theory of Reasoned Action as the foundation of his model (technology acceptance model), since it was usable in various research fields like education, health, and social science. The Technology Acceptance Model was first introduced to determine the extent of technology adoption or use by individuals and organizations [11]. TAM is widely considered to be one of the most practical models in various fields. It has shown great potential in explaining and predicting user behavior toward information technology. This feature has turned it to the most preferable model to explore the acceptance of e-learning [12]. There are four factors explaining technology usage in the original TAM: perceived ease of use (PEOU), perceived usefulness (PU), attitude, and intention to use [11]. Perceived ease of use concerns the degree to which a person believes that utilizing a special system would be free of effort, whereas perceived usefulness is delineated as the degree to which a person believes that utilizing a special system improves his or her quality [11]. In the original formulation of TAM, attitude plays a mediating role between the two mentioned variables (PEOU, PU) and the intention to use.

In 1986, Bandura produced Social Cognitive Theory or the "social foundations of thought and action". The conceptual outlook of SCT asserts that human performance should 
be regarded as the production of a dynamic interaction of personal behavior, and milieu influences [12]. Davis [11] mentioned Bandura's social cognitive theory that defined selfefficacy as "judgments of how well one can perform courses of action essential in dealing with expected status" (as cited in [9], p.34). Self-efficacy refers to beliefs in one's abilities to organise and perform the courses of action essential in producing given outcomes ([13], p.7).

Innovation Diffusion Theory (IDT) is the basis of most existing studies on innovation adoption and diffusion. This theory is often used to explain and foresee adoption and diffusion behavior [14]. It is the most famous theory about technical alteration. IDT has been vastly used in variety of fields like science, sociology, communication, marketing, internet, and technology [15]. An innovation is an idea, practice, or object that is considered as invention by a person or another unit of acceptance. On the other hand, diffusion is the phenomenon by which an innovation spreads through specific ways over time among the members of a social network [15]. Therefore, the IDT theory argues that potential users make decisions to adopt or reject an innovation based on arguments that they form about the innovation [16].

IDT incorporates five salient innovation characteristics: compatibility (CPT), relative advantage (RAD), complexity (CPX), trialability, and observability .Compatibility is defined as the degree of consistency between an innovation and users' values, experiences, and demands [15]. Compatibility is the extent to which an innovation is considered as consistent with the values, past experiences and needs of potential adopters [17]. Relative advantage is defined as the extent to which an innovation is considered as being superior to the idea it replaced [15]. Complexity refers to the perception of how arduous the innovation is to understand. It is conversely associated with to the rate of acceptance of an innovation [15]. Trialability is the degree to which an innovation can be tested within a certain restriction. Trialability can also be viewed as the extent to which an innovation may be tested with on a limited foundation [18]. Observability is the extent to which the effects of innovations can be perceived obviously by other people. These features are used to explain end-user adoption of new technologies and the process of making decisions [19].

This study tried to examine the following research objectives:

To examine the effect of trialability on perceived ease of use of technology.

To examine the effect of subjective norm on perceived ease of use of technology.

To examine the effect of self-efficacy on perceived ease of use of technology.

To examine the effect of compatibility on perceived usefulness of technology.

To examine the effect of trialability on perceived usefulness of technology.

To examine the effect of subjective norm on perceived usefulness of technology.

To examine the effect of self-efficacy on perceived usefulness of technology.

To examine the effect of compatibility on attitude toward using technology.

To examine the effect of trialability on attitude toward using technology.

To examine the effect of perceived ease of use on attitude toward using technology.

To examine the effect of perceived usefulness on attitude toward using technology.

According to [20] the effect of trialability on perceived ease of use is significant. Lee et.al [19] conducted a research about intention to use e-learning systems. In this study, perceived ease of use indicated to be affected strongly by trialability. The results of the study by Tran, Tran and Cheng [21] confirmed the impact of trialability on perceived ease of use. Park [12] did a study on students' intention to use e-learning, and reported the salient effect of subjective norm and self-efficacy on perceived ease of use. Rabaai [1] also found the strong effect of these two variables on perceived ease of use. In contrast to the above mentioned studies, in a research by Aypay, Çelik, Aypay and Sever [22] on technology acceptance among pre-service teachers, self-efficacy was no influential predicator of perceived ease of use. Consequently, the following hypotheses were proposed for the current piece of work: 
$\left.H_{1}\right)$ Trailability affects perceived ease of use of technology among high school English teachers.

$\mathrm{H}_{2}$ ) Subjective norm affects perceived ease of use of technology among high school English teachers.

$\left.\mathrm{H}_{3}\right)$ Self-efficacy affects perceived ease of use of technology among high school English teachers.

In a study by Jung [23], the influential factors on class enrichment were investigated and the significant and meaningful effect of compatibility, instant connectivity and selfefficacy on perceived usefulness was confirmed. Lee et.al [19] in a study showed the significant effect of trialability on perceived usefulness. The results of the study by Mutahar et al [24] was in line with [19]. Bourgonjon et al [25] did a research in the field of game-based learning and asserted the strong effect of subjective norm on perceived usefulness. The result of this study was in line with [26] who did a research about faculty perception of teaching online. In [21] they added IDT to TAM and found that compatibility had a significant impact on perceived usefulness. In another research by Isaac [17] among employees in Yemen, the influential effect of compatibility on perceived usefulness was confirmed. Dastorani and Khoshneshin [2] in a review article confirmed the effect of self-efficacy on perceived usefulness. Consequently, the following hypotheses were proposed for the purpose of the present work:

$\left.\mathrm{H}_{4}\right)$ Compatibility affects perceived usefulness of technology among high school English teachers.

$\left.\mathrm{H}_{5}\right)$ Trialability affects perceived usefulness of technology among high school English teachers.

$\left.H_{6}\right)$ Subjective norm affects perceived usefulness of technology among high school English teachers.

$\left.H_{7}\right)$ Self-efficacy affects perceived usefulness of technology among high school English teachers.

Compatibility is one of the significant factors to determine the attitude of users toward using technology [24]. In [27] they did a research in the field of e-assessment among academics and reported the strong effect of compatibility on attitude toward using technology. Shiau et al [18] asserted the significant and meaningful effect of trialability of users in using technological software on their attitude toward using technology. Yunus [28] in a study about intention to use technology found that compatibility and trialability had salient effect on intention to use via attitude. Contrary to these researchers [29] considered lecturers`attitude toward technology use, and found that from among the five components of innovation diffusion theory, compatibility and trialability showed no relationship with attitude. Consequently, the following hypothesis is proposed:

$\left.\mathrm{H}_{8}\right)$ Compatibility affects attitude toward using technology among high school English teachers .

$\left.\mathrm{H}_{9}\right)$ Trialability affects attitude toward using technology among high school English teachers.

Anni, Wan and Yono [30] who investigated the school counselors intention to use technology, found that perceived ease of use and perceived usefulness had positive effect on attitude toward using technology. This finding asserted in the work of researchers like [1], [6] and [26].Dastorani and Khoshneshin [2] did a study on Iranian university teachers' intention to use technology for academic purposes and found that the effect of perceived ease of use and perceived usefulness on attitude was significant. Consequently, the following hypotheses were proposed:

$\left.H_{10}\right)$ Perceived usefulness of technology affects attitude toward using technology among high school English teachers. 
$\left.H_{11}\right)$ Perceived ease of use of technology affects attitude toward using technology among high school English teachers.

According to the above mentioned hypotheses which were based on the literature, the hypothesised research model was proposed (Figure 1).

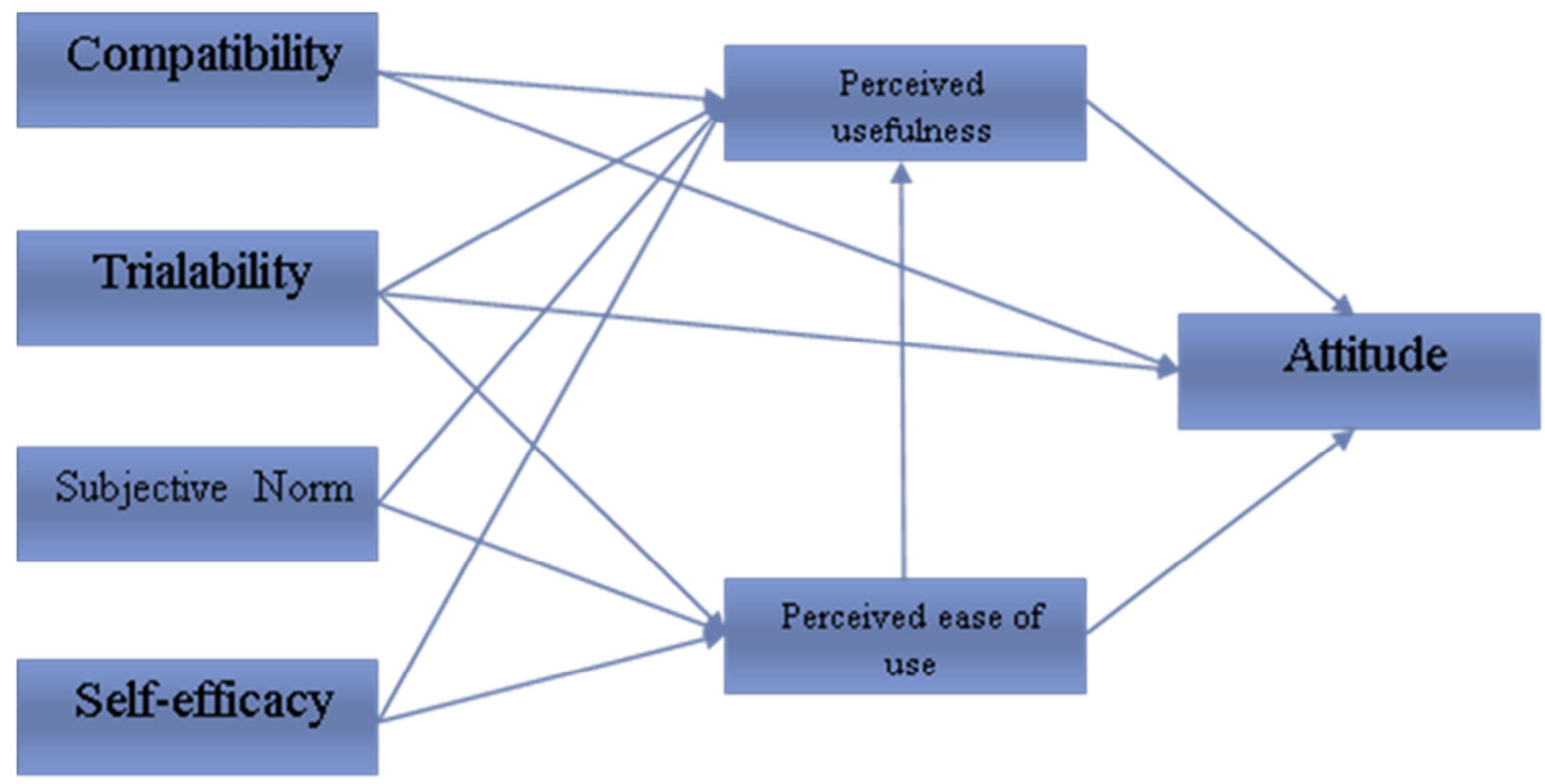

Figure1. Conceptual framework of the study

As it is indicated in this figure, there are four exogenous variables, two intervening variables and one endogenous variable. Among the exogenous variables, trialability was the only one that was supposed to have a direct effect on three variables, i.e. perceived ease of use, perceived usefulness and attitude. Other information regarding the variables and their supposed directions are also presented in Figure 1.

\section{RESEARCH METHOD}

\subsection{Participants}

Participants in this study were high school English teachers from 4 regions in Shiraz, Iran. The researcher used stratified sampling to identify a suitable sample from the population. To estimate the sample size, Krejcie and Morgan`s [31] table was used based on confidence level needed from a given population. Based on this table, from among 641 teachers 242 was recognised as the appropriate number for the sample.

\subsection{Instrumentation}

Seven questionnaires were used in the present study. All of the seven questionnaires were standard questionnaires that had been used in various places of research. Seven attitude-related statements comprised questionnaire I that was about attitude toward technology use. This measure had been developed by [32]. Questionnaire II was about perceived ease of use and questionnaire III measured perceived usefulness. Davis`s [11] perceived ease of use and perceived usefulness questionnaire had been used by [33] and they had found that it was quite valid and reliable. Each of these questionnaires had four items. Other researchers like [1], [19] and [8] had also used this instrument in their studies. Four statements comprised the measure of self-efficacy which was in 
questionnaire IV. Pederson [34] had developed this measure. The fifth questionnaire covered items related to subjective norm. The twelve items that measured subjective norms had been adopted from a questionnaire developed by [35]. The two final questionnaires covered items related to compatibility and trialability. Compatibility and trialability questionnaires were adapted from an article proposed by [29]. Each variable had five questions.

The Cronbach`s reliability coefficient alpha test was used in determining the reliability of the questionnaires. The value of alpha coefficient ranges between 0 and 1.0, with higher value indicating higher reliability among the variables. This test was conducted with a pilot data from 30 teachers. The purpose of this reliability test was to estimate the test stability over a variety of conditions. Cronbach`s reliability coefficient alpha provides a measure of the internal consistency of the items. The reliability of all variables in questionnaire was above 0.70

Table 1

\section{Cronbach`s alpha reliability}

\begin{tabular}{|l|c|}
\hline Variable & $\begin{array}{l}\text { Cronbach`s alpha } \\
\text { reliability }\end{array}$ \\
\hline Compatibility & 0.72 \\
\hline Trialability & $\mathbf{0 . 7 6}$ \\
\hline Perceived usefulness & $\mathbf{0 . 8 4}$ \\
\hline Perceived ease of use & $\mathbf{0 . 7 5}$ \\
\hline Self-efficacy & $\mathbf{0 . 8 0}$ \\
\hline Subjective norm & $\mathbf{0 . 7 8}$ \\
\hline Attitude & $\mathbf{0 . 8 2}$ \\
\hline
\end{tabular}

Content validity of the measures should have been investigated too. Content validity is the extent to which an instrument measures what is supposed to measure. In this study, content validity was established by the previously reported analysis in the literature and also by consulting two experts in the field of communication and information technology. Their comments were very conducive in clarifying the instrument to arrive at the final version. They confirmed the content and relatedness of each item with what was predicted to evaluate.

\subsection{Procedures}

Participants from various schools completed the questionnaires provided by the researcher. The questionnaires were delivered in person to each participant or group of participants (when two or more sample teachers were from the same school). In the next step, data collected via the questionnaires were coded by the researcher. The data were first recorded on SPSS software (version 24). A random sample of five percent of the entered data was checked for coding accuracy.

\section{THE RESULTS AND DISCUSSION}

\subsection{Data Analysis}

The statistical analysis comprises two stages. The first stage examines the descriptive statistics of the measurement items and assess the reliability and validity of the measures used in this study. Descriptive statistical analyses such as mean, and standard deviation, skewedness, and kurtosis are implemented using SPSS 24. Table 2 indicates each variable and the amount of statistical values. 
Descriptive statistics of the variables

\begin{tabular}{|l|l|l|l|l|}
\hline Construct & Mean & $\begin{array}{l}\text { Standard } \\
\text { Deviation }\end{array}$ & Skewedness & Kurtosis \\
\hline Att & 23.60 & 5.834 & 0.422 & $\mathbf{- 1 . 4 9 9}$ \\
\hline PEU & 13.90 & 2.024 & -0.434 & $\mathbf{0 . 3 4 0}$ \\
\hline PU & 15.40 & 2.590 & -0.456 & $\mathbf{1 . 0 5 3}$ \\
\hline SE & 16.20 & 2.394 & -0.051 & $\mathbf{- 0 . 2 2 5}$ \\
\hline SN & 45.60 & 8.448 & -0.199 & $\mathbf{0 . 3 3 8}$ \\
\hline Com & 13 & 4.784 & -0.213 & $\mathbf{- 0 . 4 8 4}$ \\
\hline Tri & 14.70 & 2.213 & 1.217 & $\mathbf{1 . 1 4 3}$ \\
\hline
\end{tabular}

As it is shown in Table 2, subjective norm has the greatest amount in mean and standard deviation. In the present study, path analysis, a form of causal modeling, is chosen as the statistical procedure for examining the relationship between teacher perceptions and the use of instructional technology. Causal modeling techniques examine whether a pattern of intercorelations among variables "fits" the underlying theory regarding which variables are influencing other variables. The first step in a path analysis is to examine the Goodness of Fit, which means how well the proposed model fits the real data. That means the hypotheses of the model should fit the collected data [36].

Table 3

Fit indices

\begin{tabular}{|l|l|}
\hline Modification index & Value \\
\hline GFI & 0.990 \\
\hline AGFI & 0.904 \\
\hline NFI & 0.964 \\
\hline CFI & 0.980 \\
\hline RMSEA & 0.078 \\
\hline X2 & 5.857 \\
\hline DF & 3 \\
\hline P & 0.119 \\
\hline
\end{tabular}

In Table 3 the ratio of $\chi 2 / d f$ is less than 3 , which indicates global fit of the data. The reported root mean square residual of approximation (RMSEA) is 0.078 , i.e., less than 0.1, which indicates a good fit. Other indications that the model fits well are the comparative fit index (CFI), which is 0.980, the goodness of fit index (GFI), which is 0.990, the adjusted goodness of fit index (AGFI) which is 0.904 and the null fit index which is 0.964 . Values are much larger than the common target of 0.9 for reflecting a good fit. Thus, it is concluded that the proposed model fit well and represents a reasonably close approximation in the population.

In the second step, the data from the returned questionnaires are analyzed to test the hypotheses. Since the model fit the data, all results are admissible and all results are reasonable in the context of the area under investigation. As a result, it is concluded that the hypothesised model is acceptable. The fit model is shown in Appendix A.

After assessing the goodness of fit of the proposed model, the hypothesised relationships between the variables are evaluated. The standardised path coefficient, T-value, and P-value are assessed to test the relationships among variables. In this study, P-value is used to evaluate how statistically significant the relationships between measured variables at the level 0.01 are. The standardised path coefficient $\beta$ means the path that illustrates a causal 
relationship between two variables [37]. It is used to estimate the effect size of the different constructs in the model. Variables` values are assessed using T-value. T-value can be estimated by dividing the regression coefficient $(\beta)$ by the standard error (SE), and it is considered significant at the 0.01 level, if the T-value is equal to or above 2.58 [37].

Table 4

Path analysis result

\begin{tabular}{|l|l|l|l|l|}
\hline $\begin{array}{l}\text { Dependent } \\
\text { variables }\end{array}$ & $\begin{array}{l}\text { Independent } \\
\text { variables }\end{array}$ & $\begin{array}{l}\text { Path } \\
\text { coefficient ( } \beta\end{array}$ & T-values & Finding \\
\hline PEU & Tri & 0.193 & 2.636 & supported \\
\hline PEU & SN & 0.366 & 4.867 & supported \\
\hline PEU & SE & 0.216 & 2.886 & supported \\
\hline PU & Com & 0.241 & 3.461 & supported \\
\hline PU & Tri & 0.174 & 2.583 & supported \\
\hline PU & SN & 0.162 & 2.602 & supported \\
\hline PU & SE & 0.198 & 2.719 & supported \\
\hline ATT & Com & 0.163 & 2.669 & supported \\
\hline ATT & Tri & 0.384 & 5.547 & supported \\
\hline ATT & PU & 0.218 & 2.963 & supported \\
\hline ATT & PEU & 0.165 & 2.632 & supported \\
\hline
\end{tabular}

In Table 4, the first row indicates the direct effect of trialability on perceived ease of use ( $\beta=0.193, \mathrm{~T}=2.636$ ). Because the value of $\mathrm{T}$ is equal to 2.636 , which is greater than 2.58 , the direct effect of trialability on perceived ease of use (0.193) is significant at 0.01 level and the first hypothesis is supported.

The second row indicates the direct effect of subjective norm on perceived ease of use $(\beta=0.366, \mathrm{~T}=4.867)$. Because the value of $\mathrm{T}$ is equal to 4.867 , which is greater than 2.58 , the direct effect of subjective norm on perceived ease of use (0.366) is significant at 0.01 level and the second hypothesis is supported.

The third row indicates the direct effect of self-efficacy on perceived ease of use ( $\beta=0.216, \mathrm{~T}=2.886$ ). Because the value of $\mathrm{T}$ is equal to 2.886 , which is greater than 2.58 , the direct effect of self-efficacy on perceived ease of use (0.216) is significant at 0.01 level. Based on the literature and this result, the third hypothesis is supported.

The forth row indicates the direct effect of compatibility on perceived usefulness ( $\beta=0.241, \mathrm{~T}=3.461$ ). Because the value of $\mathrm{T}$ is equal to 3.461, which is greater than 2.58 , the direct effect of compatibility (0.241) on perceived usefulness is significant at 0.01 level. Based on the literature and this result, the forth hypothesis is supported.

The fifth row indicates the direct effect of trialability on perceived usefulness $(\beta=0.174$, $\mathrm{T}=2.583$ ). Because the value of $\mathrm{T}$ is equal to 2.583 , which is greater than 2.58 , the direct effect of trialability (0.174) on perceived usefulness is significant at 0.01 level. Based on the literature and this result, the fifth hypothesis is supported.

The sixth row indicates the direct effect of subjective norm on perceived usefulness ( $\beta=0.162, \mathrm{~T}=2.602$ ). Because the value of $\mathrm{T}$ is equal to 2.602 , which is greater than 2.58 , the direct effect of subjective norm (0.162) on perceived usefulness is significant at 0.01 level. Based on the literature and this result, the sixth hypothesis is supported.

The seventh row indicates the direct effect of self-efficacy on perceived usefulness ( $\beta=0.198, T=2.719$ ). Because the value of $\mathrm{T}$ is equal to 2.719 , which is greater than 2.58 , the direct effect of self-efficacy (0.198) on perceived usefulness is significant at 0.01 level. Based on the literature and this result, the seventh hypothesis is supported. 
The eighth row indicates the direct effect of compatibility on attitude $(\beta=0.163$, $\mathrm{T}=2.669$ ). Because the value of $\mathrm{T}$ is equal to 2.669 , which is greater than 2.58 , the direct effect of compatibility (0.163) on attitude is significant at 0.01 level. Based on the literature and this result, the seventh hypothesis is supported.

In Table 4, the biggest direct effect relates to trialability on attitude $(\beta=0.384, \mathrm{~T}=5.547)$. Because the value of $\mathrm{T}$ is equal to 5.547 , which is greater than 2.58 , the direct effect of compatibility (0.241) on attitude is significant at 0.01 level. Based on the literature and this result, the ninth hypothesis is supported.

The tenth row indicates the direct effect of perceived usefulness on attitude $(\beta=0.218$, $\mathrm{T}=2.963$ ). Because the value of $\mathrm{T}$ is equal to 2.963 , which is greater than 2.58 , the direct effect of perceived usefulness (0.218) on attitude is significant at 0.01 level. Based on the literature and this result, the tenth hypothesis is supported.

The eleventh row indicates the direct effect of perceived ease of use on attitude ( $\beta=0.165, \mathrm{~T}=2.632$ ). Because the value of $\mathrm{T}$ is equal to 2.632 , which is greater than 2.58 , the direct effect of compatibility (0.165) on attitude is significant at 0.01 level. Based on the literature and this result, the eleventh hypothesis is supported.

Table 5 represents the correlation among variables. The correlation of all items with inclination of technology acceptance is proved by meaningful sig $(\mathrm{P}<0.01)$.

Table 5

\section{Correlation matrix}

\begin{tabular}{|c|c|c|c|c|c|c|c|}
\hline Construct & \multicolumn{1}{|c|}{ TRI } & \multicolumn{1}{|l|}{ PEOU } & PU & SN & COM & SE & ATT \\
\hline Trialability & 1 & & & & & & \\
\hline Perceived Ease of use & $.170^{*}$ & 1 & & & & & \\
\hline Perceived Usefulness & $.187^{*}$ & $.260^{* *}$ & 1 & & & & \\
\hline Subjective-norm & .130 & $.288^{* *}$ & $.350^{* *}$ & 1 & & & \\
\hline Compatibility & .031 & .056 & $.272^{* *}$ & $.170^{*}$ & 1 & & \\
\hline Self-efficacy & .112 & .149 & $.199^{*}$ & $.242^{* *}$ & .080 & 1 & \\
\hline Attitude & $.406^{* *}$ & $.161^{*}$ & $.377^{* *}$ & $.302^{* *}$ & $.249 * *$ & $.175^{*}$ & $\mathbf{1}$ \\
\hline
\end{tabular}

The highest score for correlation belonged to attitude and trialability, meanwhile the lowest score was between compatibility and trialability. Other correlations were illustrated in Table.5.

\section{CONCLUSION}

Based on technology acceptance model, innovation diffusion theory and other influential theories and models, the aim of this study was to investigate what factors affect technology acceptance in high schools from teachers` point of view. Nowadays, with vast use of technology in every situation, the importance of technology acceptance is inevitable. The hypothesised research model was driven based on the literature, and stated in the form of research hypothesis. As discussed in the result section of the present study, the correlation between variables is acceptable, and it indicates a significant and positive relationship among variables. The findings of the present study is in line with [6], [1] and [30] which emphasised the effect of perceived ease of use and perceived usefulness on attitude toward technology use. Findings of the present study were aligned with [1] and [12] which explained the impact of subjective norm and selfefficacy on perceived ease of use. Also, the findings of the present study are in accordance with [2] and [23] which confirmed the effect of subjective norm and self-efficacy on perceived 
usefulness. Findings of [24] and [19] showed the effect of trialability on perceived ease of use. In [19], [24] and [25] the significant effect of compatibility and trialability on perceived usefulness were confirmed. In this study the effect of the two components of innovation diffusion theory, i.e. compatibility and trialability, on perceived usefulness was approved. [18], [28] and [29] confirmed the relationship between compatibility and trialability with attitude toward technology. This finding is in line with the finding of the present study. Preparation of suitable environment to activate technology utilization process in high schools is grounded in compatibility and ease of use for teachers and students. Trialability or the degree of testing in certain restrictions, as shown in Table 4, $\mathrm{p}$ is the most significant and effective variable in forming attitude toward using technology. Technology and technology-based environments may have a great potential in promoting socio-economic changes in different countries. In Iranian high schools, which are going to boost their educational systems, it is suggested to establish suitable environment physically and practically for both students and teachers to interact technology with ease in minimum time.

\section{REFERENCES (TRANSLATED AND TRANSLITERATED)}

[1] A. Rabaa'i, "Extending the Technology Acceptance Model (TAM) to assess students' behavioral intentions to adopt an e-learning system: The case of Moodle as a learning tool", Journal of emerging trends in engineering and applied sciences, vol.7,no.1,pp. 13- 30, 2016.(in English)

[2] M. Dastorani, Z. Khoshneshin, "An analytic review on the factors that affect Technology Acceptance Model (TAM) in Iranian universities", Interdisciplinary Journal of Virtual Learning in Medical Science, vol.2, no.8, 2017. (in English)

[3] A. AL-Ghamdi, "Investigating Factors Affecting Customers of Using Internet Banking: A Comparison study between Saudi Arabiaand the UK" (Doctoral dissertation), Brunel Business School, 2009. (in English)

[4] H.S. Park, "Factors that affect information technology adoption by teachers, (Doctoral dissertation", Nebraska, 2004. (in English)

[5] T. Teo, "Factors influencing teachers' intention to use technology: Model development and test", Computers \&Education, doi: 10.1016/j.compedu.2011.06.008. (in English)

[6] I. Arpaci, "A Study on the adoption of scratch by pre-service information technology teachers", Educational Technology \& Society, vol.2, no.1, pp. 77-86, 2015. (in English)

[7] M. Fishbein, I. Ajzen, "Belief, attitude, intention and behavior: An introduction to theory and research", MA: Addison - wesely, 1975. (in English)

[8] V. Venkatesh, F.D. Davis, "A theoretical extension of the technology acceptance model: four longitudinal field studies". Management Science, vol.46, no.2 , pp.186-204, 2000. (in English)

[9] J.A. Smith, "The Effect of Social Presence on Teacher Technology Acceptance, Continuance Intention, and Performance in an Online Teacher Prof essential Development Course"(Unpublished doctoral dissertation), University of Central Florida, Orlando, 2006. (in English)

[10] M. Delice, "Explanation of police officers`information technology acceptance using the technology acceptance model and social cognitive theory" (Unpublished doctoral dissertation), University of Louisville, 2009. (in English)

[11] F. Davis, "Perceived usefulness, perceived ease of use, and user acceptance of information technology", MIS Quarterly, vol.13, pp.319-340, 1989. (in English)

[12] S.Y. Park, "An Analysis of the Technology Acceptance Model in Understanding University Students' Behavioral Intention to Use e-Learning", Educational Technology \& Society, vol.12, no.3, pp. 150-162, 2009. (in English)

[13] S. Kulviwat, H.Y. Sonya Hsu,"An integrative framework of technology acceptance model and personalization in mobile commerce", International journal technology marketing, vol. 1, no. 4, pp.393-410, 2006. (in English)

[14] R. Agarwal, J. Prasad, "The role of innovation characteristics and perceived voluntariness in the acceptance of information technologies". Decision Sciences, vol.28, no.3, pp.557-582, 1997. (in English)

[15] E.M. Rogers, "Diffusion of Innovation", $4^{\text {th }}$ ed. Free Press, NewYork, NY, 1995. (in English)

[16] R. Agarwal, E. Karahanna, "Time flies when you're having fun: Cognitive absorption and beliefs about information technology usage". MIS Quarterly, vol. 24, no.4, pp.665-694, 2000. (in English)

[17] O. Isaac, Z. Abdullah, T. Ramayah, A. Mutahar, \& I. Alrajawy, "Perceived usefulness, perceived ease of use, perceived compatibility, and net benefits: an empirical study of internet usage among employees in Yemen", International conference on postgraduate education, vol.7, pp. 899-919, 2016. (in English)

[18] S.J.H. Shiau, Ch.Y. Huang, Ch.L. Yang, \& J.N. Juang, "A derivation of factors influencing the innovation diffusion of the open street map in STEM education", Sustainability, vol.10, no.3447, pp. 1-29, 2018. (in English) 
[19] Y.H. Lee, Y.C. Hsieh, \& C.N. Hsu, "Adding Innovation Diffusion Theory to the Technology Acceptance Model: Supporting Employees' Intentions to use E-Learning Systems". Educational Technology \& Society, vol.14, no.4, pp. 124-137, 2011. (in English)

[20] Zh. Nan, G. Xunhua, \& Ch. Guoqing, "IDT-TAM integrated model for IT adoption", Tsinghua science and technology, vol.13, no.3, pp. 306-311, 2008. (in English)

[21] T.C.T. Tran, M.Sh. Cheng, "Adding innovation diffusion theory to technology acceptance model: understanding consumers' intention to use biofuels in Viet Nam", International review of management and business research, vol.6, no.2, pp.595-609, 2017. (in English)

[22] A. Aypay, H. CoşkunÇelik, A. Aypay, \& M. Sever, "Technology acceptance in education: A study of preservice teachers in Turkey", The Turkish online journal of educational technology, vol.11, no.4, pp.264-272, 2012. (in English)

[23] H.J. Jung, "Fostering an English teaching environment: factors influencing English as a foreign language teachers' adoption of mobile learning". Informatics in Education, vol.14, no.2, pp.219-241, 2015. (in English)

[24] A. Mutahar, N. MohdDaud, T. Ramayah, O. Isaac, \& I. Alrajawy, "Integration of innovation diffusion theory (IDT) and technology acceptance model (TAM) to understand mobile banking acceptance in Yemen: the moderating effect of income", International journal of soft computing, vol.12, no.3, pp.164-177,2017. (in English)

[25] J. Bourgonjon, F. Grove, C. Smet, J.V. Jan Van Looy, R. Soetaert, \& M. Valcke, "Acceptance of game-based learning by secondary school teachers", Computers \& education,2013, vol.67, pp.21-35. (in English)

[26] N.P. Wingo, N.V. Ivankova, \& J.A. Moss, "Faculty perceptions about teaching online: exploring the literature using the technology acceptance model as an organizing framework", Online Learning, vol.21, no.1, pp.15-35. doi: 10.10.24059/olj.v21i1.761, 2017. (in English)

[27] N. Alruwais, G. Wills, \& M. Wald, "An evaluation of the model of acceptance of e-assessment among academics in Saudi universities", Education Journal, vol.2, no.7, pp. 23-36, 2018. (in English)

[28] M. Yunus, "Diffusion of innovation, consumer attitudes and intentions to use mobile banking", Information and Knowledge Management, vol.4, no.10, pp.12-18, 2014. (in English)

[29] T.J. Ntemana, W. Olatokun, "Analyzing the influence of diffusion of innovation attributes on lecturers`attitudes toward information and communication technologies", An Interdisciplinary Journal on Humans in ICT Environments, vol.8, no.2, pp.179-197,2012. (in English)

[30] C. Anni, S. Wan, \& H. Yono, "School Counselors' Intention to Use Technology: The Technology Acceptance Model", The Turkish online journal of educational technology, vol.17, no.2, pp.120-124, 2018. (in English)

[31] R.V. Krejcie, D.W. Morgan, "Determining sample size for research activities. Educational and psychological measurement", 1970. (in English)

[32] D. Compeau, C.A. Higgins, "Social Cognitive Theory and Individual Reactions to Computing Technology: A Longitudinal Study", MIS Quarterly, vol. 23, no. 2, pp.145-158, 1995. (in English)

[33] L. Adam, F. Woods, "An investigation of the impact of information and communication technologies in subSaharan Africa". Journal of Information Science, vol.25, no.4, pp.307-318, 1999. (in English)

[34] P. Pedersen, "Adoption of Mobile Internet Services: An Exploratory Study of Mobile Commerce Early Adopters" (working paper), 2003. (in English)

[35] H.R. Marcinkiewicz, N.G. Regstad, "Using subjective norms to predict teachers' computer use". Journal of Computing in Teacher Education, vol.13, no.1, pp.27-33, 1996. (in English)

[36] B.M. Byrne, "Structural equation modeling with M-plus: Basic concepts, applications, and programming". Routledge, 2013. (in English)

[37] J.F. Hair, R.F. Anderson, B.J. Babin, \& W.C. Black, "Multivariate Data Analysis", Seventh Ed. Prentice Hall Higher Education, 2010. (in English)

Text of the article was accepted by Editorial Team 25.12.2019

\section{ВПЛИВ ПСИХОЛОГІЧНИХ ФАКТОРІВ НА СТАВЛЕННЯ ВИКЛАДАЧІВ АНГЛІЙСЬКОЇ МОВИ ДО ТЕХНОЛОГІЙ: ДОСЛІДЖЕННЯ В ІРАНІ}

Сомайя Давуді

Ісламський університет Азад, Шираз, Іран

davodi.2011@gmail.com

\section{Лейла Акбарпур}

кандидат педагогічних наук, доцент

Ісламський університет Азад, Шираз, Іран

akbarpourleila@yahoo.com

\section{Есан Хадіпур}

кандидат педагогічних наук, доцент

Ісламський університет Азад, Шираз, Іран

e.ehadipour@gmail.com 


\begin{abstract}
Анотація. 3 огляду на швидкий розвиток інформаційних і комунікаційних технологій у статті наголошено на важливості їх використання в освітньому процесі. 3 метою ефективного використання технологій у процесі викладання англійської мови варто зосередитись на таких стратегіях, як інтегрування нових методів навчання 3 використанням технологічних інструментів, ефективного програмного забезпечення і створення інтерактивного середовища навчання. Метою даного дослідження $є$ вивчення впливу психологічних факторів на ставлення вчителів до використання технологій. У цьому дослідженні зазначені найбільш універсальні моделі з використанням технологій, які є основою для розробки концептуальної структури. Представлені моделі дають можливість розглянути такі змінні, як-от: сприймана корисність, сприймана простота використання, самоефективність, суб'єктивні норми, сумісність, апробація і ставлення до технологій. У проведенні дослідження взяли участь викладачі англійської мови старшої школи в Ширазі. Дослідники використовували стратифіковану вибірку для визначення відповідної вибіркової сукупності. 3 метою оцінки змінних у дослідженні було використано п'ять опитувальників. Для визначення внеску кожної незалежної змінної в передбачення залежної змінною отримані дані були проаналізовані шляхом пат-аналізу. Встановлено, що самоефективність, суб'єктивні норми, сумісність i апробація є визначальними факторами сприйманої корисності. Водночас сприймана простота використання залежить тільки від самоефективності, суб'єктивних норм і апробації, що, своєю чергою, визначає ставлення викладачів до використання технологій у навчальному процесі. На підставі отриманих результатів вважаємо, що має сенс враховувати вплив можливості тестування, а також сприйману корисність на ставлення викладачів до використання технологій(що на ставлення викладачів до використання технологій впливає корисність їх сприймання). Суб'єктивні норми, як і ефективність, мають непрямий, але важливий вплив на ставлення викладачів до використання технологій.
\end{abstract}

Ключові слова: ставлення вчителів; сприймана корисність; сприймана простота використання; самоефективність; суб'єктивні норми; апробація.

\title{
ВЛИЯНИЕ ПСИХОЛОГИЧЕСКИХ ФАКТОРОВ НА ОТНОШЕНИЕ ПРЕПОДАВАТЕЛЕЙ АНГЛИЙСКОГО ЯЗЫКА К ТЕХНОЛОГИЯМ: ИССЛЕДОВАНИЕ В ИРАНЕ
}

\author{
Сомайе Давуди \\ Исламский университет Азад, Шираз, Иран \\ davodi.2011@gmail.com \\ Лейла Акбарпур \\ кандидат педагогических наук, доцент \\ Исламский университет Азад, Шираз, Иран \\ akbarpourleila@yahoo.com \\ Эсан Хадипур \\ кандидат педагогических наук, доцент \\ Исламский университет Азад, Шираз, Иран \\ e.ehadipour@gmail.com
}

\begin{abstract}
Аннотация. Учитывая быстрое развитие информационных и коммуникационных технологий, авторы статьи подчеркнули важность их использования в образовательном процессе. Для того, чтобы способствовать использованию технологий в процессе преподавания английского языка, учителям необходимо сосредоточиться на таких стратегиях, как интегрирование новых методов обучения с использованием технологических инструментов, эффективного программного обеспечения и создание интерактивной среды обучения. Целью настоящего исследования является изучение влияния психологических факторов на отношение учителей к использованию технологий. В этом исследовании указаны наиболее универсальные модели с использованием технологий, которые являются основой для разработки концептуальной структуры. Представленные модели дают возможность рассмотреть такие переменные, как: воспринимаемая полезность, воспринимаемая простота использования, самоэффективность, субъективные нормы, совместимость, апробация и отношение к технологиям. В проведении исследования приняли участие преподаватели английского языка старшей школы в Ширазе. Исследователи использовали стратифицированную выборку для определения подходящей выборочной совокупности. С целью оценки переменных в исследовании было использовано
\end{abstract}


пять вопросников. Для определения вклада каждой независимой переменной в предсказание зависимой переменной полученные данные были проанализированы путем пат-анализа. Установлено, что самоэффективность, субъективные нормы, совместимость и апробация являются определяющими факторами воспринимаемой полезности. В то же время, воспринимаемая простота использования зависит только от самоэффективности, субъективных норм и апробации, что, в свою очередь, определяет отношение преподавателей к использованию технологий в учебном процессе. Полученные результаты предполагают, что имеет смысл учитывать влияние возможности тестирования, а также воспринимаемую полезность на отношение преподавателей к использованию технологий. Субъективные нормы, так же как и эффективность, оказывают косвенное, но важное влияние на отношение преподавателей к использованию технологий.

Ключевые слова: отношение учителей; воспринимаемая полезность; воспринимаемая простота использования; самоэффективность; субъективные нормы; апробация.

\section{Appendix A}

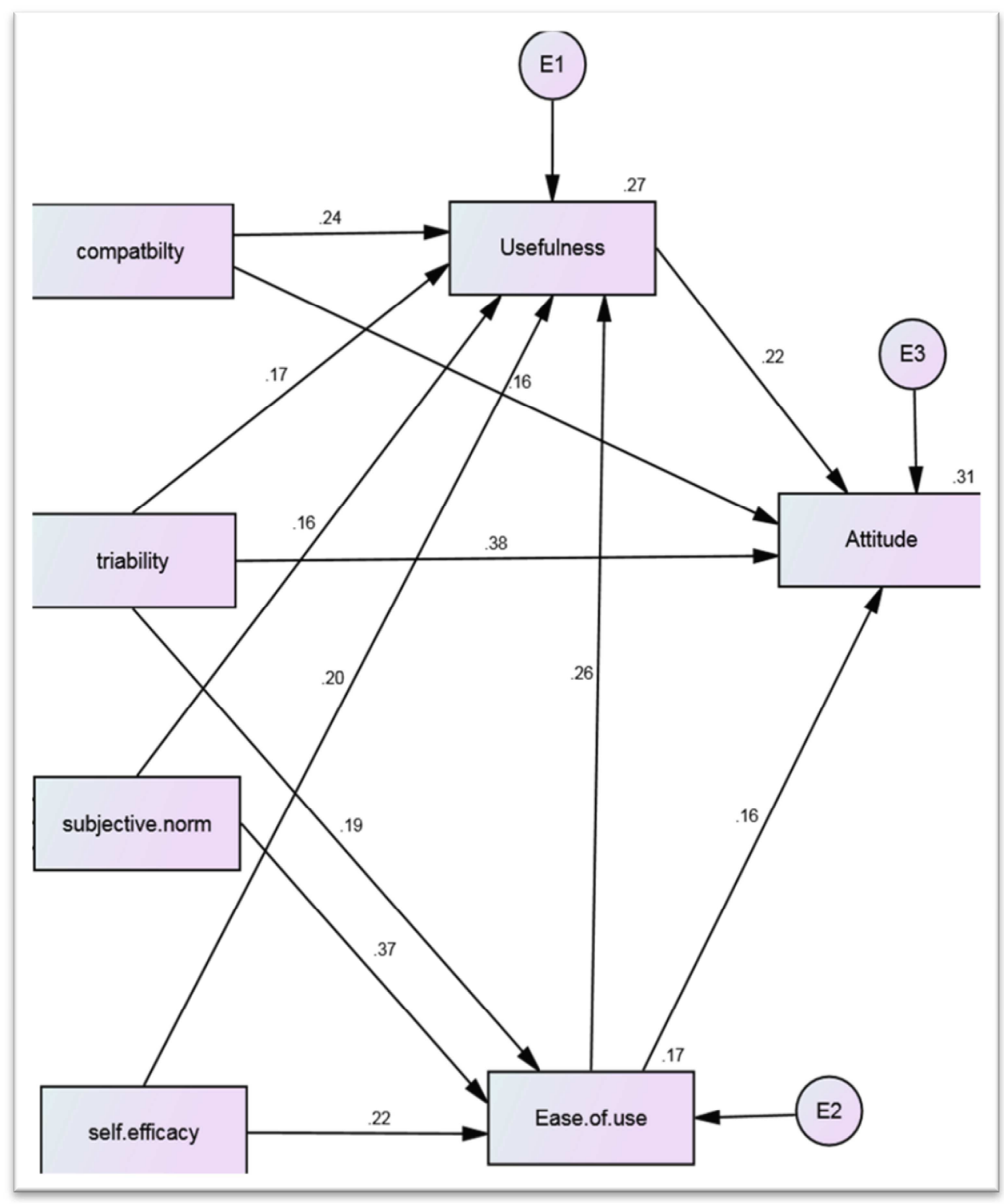

Figure 2. Fitted model

\section{(c) EY-NC-SA}

This work is licensed under Creative Commons Attribution-NonCommercial-ShareAlike 4.0 International License. 